\title{
PLAN TO USE GLACIERS FOR IRRIGATION IN GHINA
}

THE following is an extract from an article by the Hongkong Correspondent of The Times, reprinted by permission from The Times of it March i $96 \mathrm{I}$ :

For the first time, Chinese scientists have made a detailed survey of the Tien Shan and claim to have solved the problems governing the accumulation and thawing of the snow and ice in these great mountains that run east and west for more than I, ooo miles, dividing the potentially rich province of Sinkiang into two.

Six field teams have been engaged for two years, under the auspices of the Chinese Academy of Sciences, and Peking and other universities, in investigating the distribution of the glaciers and rivers, the total water stored from accumulated snow and ice and other matters. Their findings will now be used to help the expansion of agriculture, afforestation, and livestock breeding in this region.

In one part of western Sinkiang, where rainfall is plentiful, a glacier 20 miles long [32 km.] has caused floods every year. It has blocked the only passage between north and south and damaged crops in the area.

The surveying teams have now worked out a method of using the boulders and stones carried down by the glacier to build dams to hold the water. They have also outlined a plan to use the water to generate electricity.

Water control projects in the past i I years have already contributed to greater farm production, but plans for the reclamation of millions of acres of waste land in the dry areas of the north-west depend upon the discovery of much greater supplies of water.

The precipitation in the areas of the Kilien Shan, Tien Shan, Kuenlun, Altai and other great ranges in far western China is generally many times that of the almost arid plains. Only part of the water flows down, while an immense amount remains trapped on the mountains in the form of glaciers, snow, ice floes [sic], lakes and springs.

Estimates based on aerial photographs and topographical maps put the total water resources of the mountain glaciers alone at some $500,000 \mathrm{~m}$. cubic metres, five times as great as the total annual surface run-off in the north-west.

It is reported that in $1959,19 \mathrm{~m}$. cubic metres of water was made available for farmland by groups of people sent out by the local governments in Kansu. They have hastened the melting of mountain ice and snow by laying black material on the surface.

Another method, tried in the Kilien Shan range, has been to build drainage canals for the melting snow to converge at a certain point on the mountain slope, and then lead the melt water on to farmlands on the plain. Lakes on the mountains are to be turned into storage reservoirs by building sluice gates to control the outlets, and water may be diverted from one river to another for irrigation. Even artificial rainfall in the cloudy mountainous areas has achieved marked results.

It is believed that by making use of potential water resources the great deserts in the northwest can be conquered, and that some of them, engulfed by shifting sands like the Maowusu desert in Shensi and parts of the Little Tengri desert in eastern Inner Mongolia, can be turned into good farmland.

China has conducted a systematic fight against the deserts since the $195^{8}$ conference which laid down long-term plans with this aim.

The report concludes "that the Chinese authorities believe that if irrigation can be improved many of the desert areas of China could become available for immigration on a very
large scale". 